\title{
INTERNALISASI NILAI KERJASAMA PADA KULIAH KERJA MAHASISWA BERBASIS PARTICIPATORY ACTION RESEARCH SEBAGAI UPAYA MEWUJUDKAN KEPEDULIAN SOSIAL
}

(Studi Kasus Pengembangan Model di IAIN Syekh Nurjati Cirebon)

\author{
Deden Sudirman \\ Fakultas Psikologi UIN Sunan Gunung Djati Bandung, Jl. A.H Nasution No. 105 Bandung \\ email: dedensudirman@gmail.com
}

\begin{abstract}
ABSTRAK
Penelitian ini mengembangkan model internalisasi nilai kerjasama pada Kuliah Mahasiswa berbasis "Participatory Action Reserach" . partisipan adalah mahasiswa IAIN Syekh Nurjati Cirebon dengan menggunakan desain penelitian kualitatif. Hasil menunjukkan bahwa kuliah kerja mahasiswa berbasis participatory action research dilakukan secara berkelompok sejak persiapan, pelaksanaan dan evaluasi. Proses internalisasi nilai kerjasama pada KKM berbasis PAR terjadi saat mahasiswa melakukan Mapping, Seasonal Calender, Diagram Venn, Time Line, Trend and Change, Matrix Rangking dan Diagram alur. Model partisipatif dapat dikembangkan dari sisi tujuan, isi, metode, dan evaluasi.
\end{abstract}

Kata Kunci: Internalisasi, Kerjasama, Pembelajaran Nilai, Participatory Action Research

ABSTRACT

This research evelop teamwork internalization model through internship which is based on Participatory Action Research. Participants are students at IAIN Syekh Nurjati Cirebon involved in qualitative deasign. Result shows that internship based on Participatory Action Research has been conducted in group from preparation, implementation, until evaluation. Internalization process of cooperative values in internship occurs when the students have dinamic, participative and collaborative learning making process in making Mapping, Seasonal Calender, Diagram Venn, Time Line, Trend and Change, Matrix ranking and flowchart. Partisipative model can be developed on purpose, content, method, and evaluation

Kata Kunci: Internalization, Cooperation, learning values, Participatory Action Research

\section{PENDAHULUAN}

Fenomena rapuhnya nilai-nilai kerjasama seperti: miskin pengabdian, miskin kepedulian sosial, kurang disiplin, kurang empati terhadap masalah sosial ialah istilah yang erat kaitannya dengan lemahnya prosocial behaviour. Bartal (1976:4) menyatakan bahwa '...helping, aiding, sharing, donating, or assisting' disebut prosocial behavior, ... to describe 
behavior which was the antithesis of aggressive behavior, namely sympathy, altruism, charity, sharing, etc. Antitesis dari perilaku agresif seperti: simpati, altruisme, kasih sayang, dan saling berbagi. Maka nilai kerjasama merupakan bentuk perilaku altruistik dan atau restitusi, tingkah laku yang menimbulkan konsekuensi positif bagi kesejahteraan fisik maupun psikis orang lain.

Pentingnya kepedulian sosial dan salah satu berbentuknya ialah kerjasama antara satu dengan lainnya dengan penuh empati ditandai dengan kearifan lokal telah menjadi nilai tersendiri dalam konteks pengembangan model. Alwasilah (2009:12) menyatakan: "Kebutuhan untuk membina generasi yang akan datang dengan kemampuan menyusun kerangka moral imajinatif kian penting bukan saja untuk menyelesaikan persoalan dalam cara-cara yang rasional dan saling menghargai, tetapi juga penting untuk menjaga keutuhan masyarakat Indonesia yang majemuk. Karena itu, empati dan toleransi menjadi nilai dasar yang perlu terus dikembangkan baik dalam proses maupun sebagai output pendidikan."

Pentingnya kerukunan diungkapkan Suseno M.F ( 984:38-81) bahwa gotong royong (menekankan kerjasama), padhapadha (menekankan kesamaan), dan tepa selira (menekankan tenggang rasa) (Koentjaraningrat, 1961:43), ialah salah satu bentuk nilai social yang sangat tinggi nilainya. Dalam bahasa agama, makna kerjasama memiliki porsi tersendiri (Q.S al-Maidah 5:2),yakni: tolong-menolong dengan rela saling berkorban (birr) dan memelihara solidaritas dan ikatan social (takwa), dan tidak berbuat kriminal dan konflik komunal.

Tatanan ini menghendaki moralitas komunal menjadi core value yang melandasi proses pembudayaan, pembiasaan, pembelajaran, dan peneladanan (internalisasi). Proses in terjadi pada Kuliah Kerja Mahasiswa (KKM) berbasis Participatory Action
Research (PAR), model pengabdian masyarakat yang dikembangkan IAIN Syekh Nurjati sejak tahun 2005 hingga sekarang. Dari permasalahan tersebut, penulis meneliti keadaan, situasi dan pengembangan model internalisasi nilai kerjasama pada KKM berbasis PAR di IAIN Syekh Nurjati Cirebon.

Fokus penelitian ini untuk merumuskan"langkah-langkah

pengembangan model internalisasi nilai kerjasama pada Kuliah Kerja Mahasiswa berbasis Participatory Action Research dalam mewujudkan kepedulian sosial?", dengan rumusan masalah, yaitu: "unsurunsur pembelajaran apakah yang dapat dikembangkan dari internalisasi nilai kerjasama pada Kuliah Kerja Mahasiswa berbasis Participatory Action Research dalam mewujudkan kepedulian sosial" Rumusan masalah tersebut dikembangkan dalam bentuk pertanyaan penelitian sebagai berikut:

1) Bagaimana pelaksanaan internalisasi nilai kerjasama pada Kuliah Kerja Mahasiswa berbasis Participatory Action Research di IAIN Syekh Nurjati Cirebon?;

2) Situasi kerjasama seperti apa dalam internalisasi nilai kerjasama pada Kuliah Kerja Mahasiswa berbasis Participatory Action Research di IAIN Syekh Nurjati Cirebon?;

3) Upaya apa yang dapat dilakukan dalam mengembangkan internalisasi nilai kerjasama pada Kuliah Kerja Mahasiswa berbasis Participatory Action Research di IAIN Syekh Nurjati Cirebon?

Secara umum, penelitian ini bertujuan menghasilkan rumusan hipotetik pengembangan model internalisasi nilai kerjasama pada Kuliah Kerja Mahasiswa berbasis Participatory Action Research sebagai upaya mewujudkan kepedulian sosial. Sedangkan secara khusus tujuan penelitian ini berupaya mendeskripsikan, merumuskan dan menganalisis dari sisi 
program, proses pembelajaran atau internalisasi nilai dan upaya yang dapat dilakukan lebih lanjut dalam mengembangkan Kuliah Kerja Mahasiswa berbasis Participatory Action Research di IAIN Syekh Nurjati Cirebon. Studi ini diharapkan dapat memberi manfaat untuk: (1) menemukan indikator-indikator penting nilai kerjasama yang dapat dikembangkan melalui KKM berbasis PAR dan faktorfaktor yang berpengaruh terhadap nilai kerjasama dan memetakan kerangka pengembangan model teoritis; (2) merumuskan upaya-upaya yang bisa dilakukan atau langkah-langkah operasional dan model pembinaan yang bisa diterapkan dalam membina dan mengembangkan nilai kerjasama melalui KKM berbasis PAR.

\section{Kerangka Teori}

1. Internalisasi Nilai Kerjasama

Dari segi bahasa, "internalisasi" ialah berasal dari kata kerja "internalize", ... to make attitudes, feelings, beliefs, etc fully part of one's personality by absorbing them through repeated experience of or exposure to them, Horby (1995: 624). Di kamus lain disebutkan, kata kerja "internalize" ialah ...(1) to incorporate within oneself (the cultural values, mores, etc., of others) through learning, socialization, or identification. (2) to make subjective or give a subjective character to, (Hill,Mcgraw ,1991:648). Internalisasi hakikatnya adalah sebuah proses menanamkan sesuatu, keyakinan; sikap dan nilai-nilai yang menjadi perilaku moral Sedangkan internalisasi nilai-nilai kerjasama adalah sebuah proses menanamkan nilai-nilai kerjasama. Internalisasi ini dapat ditanamkan melalui pintu lembaga pendidikan formal, non formal dan informal. Terdapat dua kategori kerjasama, yakni: (1) kemitraan, equal commitment dan the state of being a partner, Collins English Dictionary (1991) dan to be one of a pair on the same side in a game, a person who shares or takes part with another, especially in a business firm with shared risks and profits, The Concise Oxford Dictionary (1992): dan (2) kolaborasi, cooperate traitorously with an enemy dan work jointly, the Concise Oxford Dictionary (1992). Jadi kemitraan lebih diarahkan pada kerjasama yang memiliki kesetaraan satus, fungsi dan peran dalam melakukan sesuatu, sedangkan kolaborasi ialah kerjasama yang cenderung destruktif, walau bisa saja konstruktif. Nilai sosial adalah sebuah konsep abstrak dalam diri manusia mengenai apa yang dianggap baik dan apa yang dianggap buruk, indah atau tidak indah, dan benar atau salah. Nilai sosial adalah nilai yang dianut oleh masyarakat, mengenai apa yang dianggap baik dan apa yang dianggap buruk. Sebagai contoh, orang menganggap menolong memiliki nilai baik, sedangkan mencuri bernilai buruk. Raven (1977: 220) menyatakan bahwa "social values are set of society attitude considered as a truth and it is become the standard for people to act in order to achieve democratic and harmonious life". Nilai-nilai sosial merupakan seperangkat sikap individu yang dihargai sebagai suatu kebenaran dan dijadikan standard. Nilai-nilai sosial ini, Raven (1977: 221-227) terdiri dari: (1) loves (kasih sayang) yang terdiri atas: pengabdian, tolong-menolong, kekeluargaan, kesetiaan, dan kepedulian; (2) responsibility (tanggung jawab) yang terdiri atas nilai rasa memiliki, disiplin, dan empati; dan (3) life harmony (keserasian hidup) yang terdiri atas nilai keadilan, toleransi, kerjasama, dan demokrasi.

2. Kuliah Kerja Mahasiswa berbasis Participatory Action Research

Kuliah Kerja Mahasiswa berbasis Participatory Action Research ialah salah satu model pengabdian 
masyarakat yang dikembangkan IAIN Syekh Nurjati Cirebon sejak tahun akademik 2005-2006 hingga sekarang. Tentunya, memiliki nilai dan implikasi terhadap pengembangan model pengabdian masyarakat berikutnya. Secara historis riset aksi didasarkan pada masyarakat ialah erat kaitannya dengan antropologi dan disiplin ilmu lain. Dalam konteks sosial demokratis, sebuah proses pengkajian riset aksi memiliki karakteristik: (1) demokratis, (2) kesetaraan, (3) liberasi dan (4) pemberdayaan, Stringer, Ernest T. (1996:10). PAR adalah sebuah pendekatan yang relatif baru dan kolaboratif dalam riset aksi (Torres, 2004). Suatu pengujian ringkas tentang sejarah riset aksi menggambarkan evolusi disain riset. Sejarah riset aksi dapat diusut dalam kaitan dengan "generasi" (Kemmis\& Mctaggart, 2005:560). Tulisan terkini Kurt Lewin tentang riset aksi tahun 1940 telah menguraikan proyek riset aksi di Amerika Serikat; bagaimanapun prinsip-prinsip positifistik mendominasi riset di Amerika Serikat yang pada saat yang sama telah mempengaruhi kemunduran temporer dalam kajian riset aksi (Kemmis, 1981). Generasi kedua, riset aksi ialah mencakup pengembangan organisasi mulai di Inggris sekitar awal tahun 1970. Bagaimanapun, generasi ketiga, peneliti tindakan/aksi ialah dari Australia dan Eropa yang muncul lebih terbuka, kritis dan riset aksi emansiipatoris (Carr\& Kemmis 1986). Generasi ke empat, riset aksi muncul melalui pergerakan sosial dalam mengembangkan dunia yang didukung oleh aktifis terkemuka Orlando Fals Borda (1988) dan Paulo Freire (1996). Mac Naughton (2001:210) yakin bahwa riset aksi generasi ke empat harus memperjuangkan emansipasi dan transformasi pendidikan dengan cara melakukan kerjasama dengan orang lain untuk merubah praktek sosial yang ada dan dengan menggunakan refleksi kritis dan kritik sosial sebagai kunci proses penelitian. Maka adalah kolaboratif, berorientasi pada perubahan dan secara terbuka politis". Istilah Participatory Action Research (PAR) telah diperkenalkan untuk membedakan pendekatan-pendekatan riset aksi dengan fokus berbeda tentang partisipasi masyarakat dalam proses penelitian. Di dalam PAR, peneliti dan praktisi adalah mitra sama. Tujuan utama PAR kemudian adalah tidak hanya pembuatan pengetahuan melainkan pemberdayaan partisipasi masyarakat.

3. Pembelajaran nilai

Ada beberapa pembelajaran nilai, diantaranya: (1) penanaman, perkembangan moral, (3) analisis, (4) klarifikasi, (5) tindakan belajar, dan (6) emosional-rasional. Semua pendekatan memiliki dasar pemikiran dan implikasi nilai sosial tersendiri. Dasar pemikiran pendekatan penanaman nilai adalah untuk menanamkan nilai-nilai yang diinginkan sebelum dipilih oleh peserta didik. Tujuan utamanya ialah untuk mensosialisasikan peserta didik pada nilai sehingga nilai-nilai sosial, moral, politik atau nilai-nilai budaya terinternalisasi. Perkembangan moral adalah untuk merangsang para peserta didik untuk mengembangkan kekuatan alasan moral mereka melalui serangkaian tahapan. Tujuannya ialah bukan sekedar peningkatan pengetahuan peserta didik tentang nilai-nilai budaya maupun menanamkan sebuah nilai eksternal pada peserta didik, tetapi lebih sebagai pendorong pola nilai terhadap peserta didik, Kohlberg (1966:19). Pendekatan analisis memandang manusia sebagai makhluk rasional yang bisa mencapai kebaikan tertinggi dengan menundukkan perasaan dan gairah terhadap logika dan metode ilmiah. Pendekatan klarifikasi adalah 
untuk membantu peserta didik menjelaskan dan mengaktualisasikan nilai-nilai pribadi. Juga membantu peserta didik mengembangkan berpikir rasional dan kesadaran emosional untuk menjelaskan pola perilaku mereka sendiri. Tujuan utama adalah untuk mencapai konsistensi antara perilaku pribadi dengan nilai-nilai lain yang dianut. Pendekatan belajar aksi adalah untuk mengembangkan kemampuan peserta didik untuk bertindak langsung dalam situasi pribadi dan sosial, sehingga mereka bisa menerapkan nilainilai pribadinya. Selain itu, mencoba untuk meningkatkan peserta didik pada pengertian masyarakat dan untuk mengembangkan kemampuan mereka memberi pengaruh dalam urusan publik. Pendekatan emosional rasional ialah upaya untuk membantu peserta didik memahami dan mengadopsi gaya hidup yang didasarkan pada perawatan dan pertimbangan untuk orang lain dan diri sendiri, McPhail (1978:5). Pendekatan ini sangat didasarkan pada keputusankeputusan moral yang dicapai baik proses afektif (emosional) maupun kognitif (rasional).

Semua pendekatan ialah berupaya agar nilai-nilai itu terinternalisasi pada seseorang. Nilai mendarah daging, internalized value adalah nilai yang telah menjadi kepribadian dan kebiasaan sehingga ketika seseorang melakukannya kadang tidak melalui proses berpikir atau pertimbangan lagi. Biasanya nilai ini telah tersosialisasi sejak seseorang masih kecil. Umumnya bila nilai ini tidak dilakukan, ia akan merasa malu, bahkan merasa sangat bersalah. Karakterisasi nilai yang terjadi pada individu dan atau masyarakat ialah terjadi melalui proses yang berlanjut dan berkesinambungan dengan menempuh tahap-tahap situasi dan keadaan tertentu, yakni: "(1) emoting/minding, (2) spiritualizing, (3) valueing, (4) taking role dan (5) taking position," A.Kosasih Djahiri (1985:28-59). Emoting/minding ialah fase menumbuhkan kesadaran, kesiapan untuk menyimak dan mau menghormati pendapat orang lain; spiritualizing ialah upaya melakukan personifikasi tentang dirinya diarahkan pada penataan situasi dan atau penciptaan situasi yang mendukung terjadinya proses spiritualisasi, valueing ialah upaya identifikasi nilai baik buruk bagi pengembangan nilai itu sendiri, taking role dan taking positian ialah upaya individu dan anggota kelompok untuk melakukan demonstrasi peran dan posisi, baik dalam konteks individu, maupun masyarakat. Semua itu merupakan sistem nilai, moral dan norma, di mana model pembelajaran baik yang bersifat pragmatik maupun prosedural ialah sama-sama diarahkan kepada pembentukan kepribadian-personality. Tahapan-tahapan sistem nilai, moral dan norma ini bisa dicapai dengan cara: (1) Identifikasi nilai, moral dan norma; (2) Teorifikasi nilai, moral dan norma; (3) Proses afektual; (4) Adjusting dan originalizing; (5) Moral performance. Pendidikan umum/nilai merupakan program pendidikan bagi semua orang dan menitikberatkan kepada internalisasi nilai pada diri seseorang agar memiliki rasa tanggung jawab terdahap diri, keluarga, masyarakat, bangsa dan warga dunia agar senantiasa berpikir kritis; konstruktif; ilmiah; menghormati gagasan orang lain; emosi stabil, dengan dilandasi prinsip-prinsip etika dan moral, Margaret Patricia Meyer (1949: 515).

\section{METODE PENELITIAN}

\section{Lokasi dan Subjek Penelitian}

Lokasi Penelitian di IAIN Syekh Nurjati Cirebon yang terletak di Jl. Perjuangan By Pass Cirebon dengan subjek utama penelitian mahasiswa/i peserta Kuliah Kerja Mahasiswa dan Dosen Pembimbing Lapangan (DPL). Penentuan lokasi ini didasarkan atas pertimbangan bahwa sejak Tahun Ajaran 2005-2006 hingga sekarang, IAIN Syekh Nurjati telah menerapkan KKM berbasis PAR sebagai pilihan 
pelaksanaan pengabdian masyarakat, yakni: Tahun Akademik 2005/2006 (6 pebruari-16 maret 2006) bertempat di kelurahan Argasunya, dan kelurahan Harjamukti Kota Cirebon dan di kecamatan Karangwareng Kabupaten Cirebon; Tahun Akademik 2006/2007 (20 Pebruari-21 Maret 2007) bertempat di Kecamatan Harjamukti dan kecamatan Lemahwungkuk Kota Cirebon; Tahun Akademik 2007/2008 (3 maret-12 april 2008) bertempat di Kecamatan Cantigi dan Kecamatan Arahan Kabupaten Indramayu dan Kecamatan Selajambe, Kecamatan Cilebak dan Kecamatan Subang Kabupaten Kuningan; Tahun Akademik 2008/2009 (25 Pebruari-6 April 2009) bertempat di Kecamatan Gebang, Kecamatan Babakan, Kecamatan Pabedilan dan Kecamatan Waled Kabupaten Cirebon.

2. Metode Penelitian

Jenis penelitian yang digunakan adalah penelitian kualitatif (qualitative research) dengan pendekatan deskriptifanalitis. Metode-metode yang digunakan dalam penelitian ini ialah metode dalam Pendidikan Umum/Nilai seperti Penanaman Nilai (Value Inculcation), Perkembangan Moral (Moral Development, Analisis Nilai (Value Analysis), Klarifikasi Nilai (Value Clarification), Belajar Aksi (Action Leaning), dan EmosionalRasional. Semua pendekatan pembelajaran ini dijadikan metode untuk menganalisis nilai. Nilai-nilai tersebut dianalisis secara kualitatif sesuai dengan konsep, prinsip, karakteristik dan prosedur penelitian kualitatif, penggunaan konsep-konsep dan klasifikasi-klasifikasi subjek penelitian yang tidak hanya melalui perspektif peneliti, melainkan melalui subjek penelitian, juga ia lebih diarahkan pada deskripsi verbal daripada deskripsi numerikal. Penelitian kualitatif ini menempuh tiga tahap yakni: (1) tahap orientasi, studi kelayakan atau feasibility research terhadap masalah dan subjek penelitian; (2) tahap eksplorasi, penyiapan instrumen-instumen penelitian yang diperlukan dan (3) tahap membercheck, upaya memperoleh validitas dan reliabilitas hasil penelitian. Sedangkan pengolahan data dilakukan dengan menggunakan teknik kategorisasi dan kodifikasi, reduksi data, display data, kesimpulan dan verifikasi.

\section{Hasil Penelitian, Pembahasan dan Temuan}

1. Kuliah Kerja Mahasiswa berbasis Participatory Action Research

Kuliah Kerja Mahasiswa berbasis Participatory Action Research berawal sejak semester genap Tahun Akademik 2005/2006 sampai sekarang. Pelaksanaan dilakukan secara berkelompok. Proses persiapan, pelaksanaan dan evaluasi dilakukan menggunakan pendekatan Participatory Action Research sebagai landasan untuk mengidentifikasi permasalahanpermasalahan sosial secara umum dan permasalahan kehidupan agama secara khusus.

Dalam pengenalan dan penghayatan, mahasiswa dituntut menguasai pembangunan masyarakat desa melalui kejelasan proses-proses perubahan terencana serta metode penyelesaian masalah-masalah berkenaan dengan kemampuan memilih dan memilah serta menggunakan keterampilan yang tepat terhadap situasi tertentu, menginventarisir dan mengindentifikasi masalah-masalah sosial keagamaan yang terjadi di masyarakat untuk kemudian dilakukan pendampingan dalam upaya pemecahan dan pencarian solusinya, serta memberi dorongan kepada masyarakat untuk mengembangkan kehidupan beragama di lingkungannya melalui ketepatan dan kecermatan observasi tentang situasi 
sosial keagamaan, masalah-masalah sosial, latar belakang struktur dan kultur masyarakat.

Fase Persiapan. Fase persiapan ini mahasiswa mengikuti pelatihan metodologis pelaksanaan Kuliah Kerja Mahasiswa pendekatan Participatory Action Research agar memahami langkah-langkah dan kegiatan yang akan dilakukan. Mereka sebagai fasilitator, katalisator dan dianamisator pembangunan. Materi-materi workshop antara lain PRA (Participatory Rural Apraisal), seperti Mapping, Seasonal Calender, Diagram Venn, Time Line, Trend and Change, Matrix rangking dan Diagram alur. Sebelum terjun langsung ke lokasi terlebih dahulu mahasiswa melakukan observasi lapangan ke lokasi KKM, yakni setelah mereka memperoleh pembekalan materi workshop dan didampingi seorang Dosen Pembimbing Lapangan (DPL).

Fase Pelaksanaan. Sebelum mahasiswa terjun langsung ke lokasi, terlebih dahulu mahasiswa mengikuti upacara pelepasan yang dilakukan Kepala Daerah Tingkat II Kota dan atau Kabupaten yang wilayahnya dijadikan lokasi Kuliah Kerja Mahasiswa dan Dosen Pembimbing dalam suatu upacara peresmian, kemudian upacara penerimaan oleh Camat Kepala Wilayah Kecamatan yang bersangkutan dikoordinasikan oleh Koordionator Wilayah. Dalam kesempatan ini mahasiswa KKM memperoleh pembekalan praktis dari pihak-pihak yang berkompeten. Untuk observasi kegiatan KKM pada fase pelaksanaan, mahasiswa melakukan kegiatan, (a)

Participatory Assesment, sosialisasi visi dan misi yang akan dikembangkan selama melaksanakan KKM, seperti mapping (pemetaan) dengan mengumpulkan data-data yang ada di masyarakat mengenai peta geografis, peta sosial keagamaan berikut merekap berbagai permasalahannya;
Participatory Planning, masingmasing kelompok KKM memilih mprogram berdasarkan hasil pengkajian data atau informasi dengan menggunakan langkah-langkah PAR seperti: Persiapan sosial, melibatkan diri secara langsung ke kehidupan sosial; Indentifikasi data, merumuskan hasil pengamatan sosial; Analisis sosial, menemukan dan menentukan isu sosial; Merumuskan masalah sosial keagamaan, mendokumentasikan gagasan yang muncul untuk mencari peluang-peluang sehingga mungkin dapat dilakukan bersama masyarakat; merumuskan rencana tindakan strategi yang dilakukan untuk menguasai permasalahan sosial kegamaan dan melakukan pengorganisasian potensi sumber daya lokal dengan berdasar key person yang ada; (c) Participatory Action seperti melakukan Secondary data review (SDR), Direct observation, Semi structured interviewing, Focus Group Discussion, Matrix Rangking, Preference Rankng and Scoring, Pairwise Ranking,Direct Matrix Ranking, Wealth Ranking, Wealth ranking, Mapping, Kalender Musim dan Diagram Venn. Teknik-teknik PAR ini dilakukan bersama masyarakat.

Fase Evaluasi, yakni: (a) penyusunan laporan hasil pelaksanaan KKM; (b) penyerahan laporan individu kepada panitia; (c) presentasi dan perbaikan laporan akhir; (d) penyerahan nilai DPL dan penguji; (e) pengumuman nilai; (f) pengambilan bukti kelulusan; (g) seminar hasil KKM; dan (h) evaluasi dan rencana tindak lanjut. Proses penilaian akhir KKM ditentukan melalui berbagai kegiatan, antara lain: (a) pembekalan mahasiswa melalui workshop/pelatihan calon peserta KKM; (b) pelaksanaan di lokasi, seperti: lokakarya lokasi/desa, kecamatan dan kabupaten, aktifitas setiap individu dan kelompok bersama masyarakat, pandangan/penilaian masyarakat 
setempat terhadap peserta KKM; (c) monitoring panitia; (d) penilaian laporan akhir dan presentasi laporan.

Pelaksanaan KKM berbasis PAR di IAIN Syekh Nurjati Cirebon memiliki mandat ideal terhadap mahasiswa, seperti: (a) mahasiswa memahami dan dapat mengimplementasikan pengabdian kepada masyarakat dengan metodologi alternatif, yakni Participatory Action Research bersama masyarakat; (b) lebih memahami berbagai teknik dalam mengkaji permasalahan dan potensi di masyarakat; (c) berkontribusi dalam menentukan alternatif-alternatif penyelesaian permasalahan bersama masyarakat dan menyusun program tindaklanjutnya; (d) memiliki rasa kepedulian sosial dan mampu bekerjasama dalam tim di tengah masyarakat.

Mengacu kepada Keputusan Direktur Jenderal Pendidikan Tinggi Departemen Pendidikan Nasional Republik Indonesia Nomor: 44/DIKTI/Kep/2006 Tentang RambuRambu Pelaksanaan Kelompok Matakuliah Berkehidupan Bermasyarakat di Perguruan Tinggi, Pasal 1 bahwa Visi Kelompok Matakuliah Berkehidupan Bermasyarakat (MBB) di perguruan tinggi "merupakan sumber nilai dan pedoman bagi penyelenggaraan program studi guna mengantarkan mahasiswa memantapkan kepribadian, kepekaan sosial, kemampuan hidup bermasyarakat, pengetahuan tentang pelestarian, pemanfaatan sumber daya alam dan Iingkungan hidup, dan mempunyai wawasan tentang perkembangan ilmu pengetahuan teknologi dan seni". Selanjutnya pada Pasal 2 Misi kelompok MBB di perguruan tinggi ialah "membantu menumbuh-kembangkan: daya kritis, daya kreatif, apresiasi dan kepekaan mahasiswa terhadap nilai-nilai sosial dan budaya demi memantapkan kepribadiannya sebagai bekal hidup bermasyarakat selaku individu dan makhluk sosial yang: (a). Bersikap demokratis, berkeadaban, dan menjunjung tinggi nilai kemanusiaan, bermartabat serta peduli terhadap pelestarian sumber daya alam dan lingkungan hidup; (b) Memiliki kemampuan untuk menguasai dasardasar ilmu pengetahuan, teknologi dan seni; dan (c) Ikut berperan mencari solusi pemecahan masalah sosial budaya dan lingkungan hidup secara arif.

Nilai-nilai dimaksud meliputi berpikir kritis, kreatif, sistemik dan ilmiah, berwawasan luas, etis, estetis, memiliki apresiasi kepekaan dan empati sosial, bersikap demokratis, berkeadaban, dan menjunjung tinggi nilai kemampuan; memiliki kepedulian terhadap pelestarian sumberdaya alam dan lingkungan hidup, mempunyai wawasan tentang perkembangan ilmu pengetahuan teknologi dan seni serta dapat ikut berperan mencari solusi pemecahan masalah sosial, budaya dan lingkungan hidup secara arif, ialah terjadi saat mahasiswa melaksanakan pengabdian masyarakat. Sedangkan Pendidikan umum merupakan program pendidikan bagi semua orang dan menitikberatkan kepada internalisasi nilai pada diri seseorang agar memiliki rasa tanggung jawab terdahap diri, keluarga, masyarakat, bangsa dan warga dunia agar senantiasa berpikir kritis; konstruktif; ilmiah; menghormati gagasan orang lain; emosi stabil, dilandasi prinsip-prinsip etika dan moral.

Pengabdian masyarakat ini dilandasi semangat Participatory Action Research yang bercirikan praktek sosial, mahasiswa memahami situasi mereka dan secara terus menerus menguji situasi mereka dengan tujuan peningkatan; partisipatoris, bukanlah 
riset yang dilakukan tentang seseorang melainkan kolaboratif dan melibatkan peserta di dalam menguji pemahaman mereka sendiri, ketrampilan dan nilainilai dan tata cara mereka membentuk diri mereka dan tindakan mereka di dalam dunia sosial; kolaboratif dan praktis, proses di mana mahasiswa menyelidiki praktek yang sering terjadi dan bertujuan membongkar hal yang tidak produktif, tidak memuaskan dan/atau tidak adil dengan tujuan peningkatan lebih lanjut; emansipatoris, membantu masyarakat melakukan pemulihan, dan pelepasan diri dari batasan-batasan tidak logis, tidak produktif, tidak adil, dan struktur sosial tidak memuaskan dan penentuan nasib sendiri; kritis, menguji dunia sosial secara bebas untuk membongkar, menyusun kembali ketidakadilan, tidak memuaskan dan tidak produktif. Kritis bermakna secara terus menerus menguji dirinya sendiri untuk mendorong praktek yang adil; reflektif, suatu proses sadar untuk mengubah bentuk kegiatan melalui suatu siklis, proses spiral dan reflektif; transformatif, kesesuaian antara teori dan praktek bertujuan untuk mengubah bentuk kedua-duanya secara timbal balik.

\section{Proses Pembelajaran Kuliah Kerja Mahasiswa berbasis Participatory Action Research}

Temuan Proses Pembelajaran (internalisasi nilai) pada Kuliah Kerja Mahasiswa berbasis Participatory Action Research meliputi: Tujuan, Bahan Ajar, Metode, Sarana, Alat atau Instrumen, dan Evaluasi.

\section{a. Tujuan}

Rumusan tujuan pembelajaran KKM berbasis PAR di IAIN Syekh Nurjati Cirebon ialah terfokus pada isu: pemberdayaan masyarakat yang partisipatif, perubahan sosial, penelitian Islam dan menghargai budaya lokal seperti tercermin pada tema dan tujuan pelaksanaan KKM, yakni:

Tema :Islam berbasis realitas untuk perubahan sosial (2006); Islam berbasis realitas untuk perubahan sosial (2007); Belajar bersama masyarakat (2008); Aktualisasi Islam Rahmatan Lil A'lamin bersama masyarakat (2009)

Tujuan : KKM dapat menjadi studi alternatif bagi penelitian Islam dan pemberdayaan untuk perubahan masyarakat dengan tetap menghargai budaya lokal (2006); Bersama masyarakat melakukan pemberdayaan untuk perubahan sehingga KKM dapat menjadi alternatif riset Islam dan pemberdayaan masyarakat di tengah dinamika masyarakat (2007); Bersama masyarakat melakukan pemberdayaan untuk perubahan sehingga KKM dapat menjadi alternatif riset Islam dan pemberdayaan masyarakat di tengah dinamika masyarakat (2008); Bersama masyarakat melakukan pemberdayaan untuk perubahan sehingga KKM dapat menjadi alternatif riset Islam dan pemberdayaan masyarakat di tengah dinamika masyarakat (2009).

Meskipun Tujuan dan Target pelaksanaan KKM berbasis PAR secara umum telah ditetapkan, namun tujuan yang terkait dengan pentingnya pembelajaran internalisasi nilai pada KKM berbasis PAR belum mendapat perhatian. Temuan peneliti menunjukkan bahwa penetapan tujuan pembelajaran internalisasi nilai dalam KKM berbasis PAR, masih berkutat di seputar peningkatan wawasan keilmuan kemasyarakatan mahasiswa secara kognitif dan kemampuan dalam melaksanakan komunikasi sosial 
dengan masyarakat. Sementara nilainilai yang mendasari tumbuhnya kepedulian dan kepekaan terhadap masyarakat belum secara sistemik didayagunakan. Padahal sebagaimana dikatakan Zais, Robert S (1976:15-16) bahwa :..kandungan kurikulum atau isi kurikulum (tujuan dan target KKM berbasis PAR, salah satu contoh) ialah akan dipengaruhi oleh Filsafat dan Hakikat Pengetahuan yang terdapat pada kurikulum itu sendiri. Filsafat dan Kurikulum ialah sama-sama diarahkan:" Dapat menjadi apa manusia itu atau What can man become ?". Filsafat berbicara tentang "manusia" dalam konteks makrokosmos atau teori umum dalam pendidikan, sedangkan Kurikulum berbicara tentang "manusia-manusia" dalam konteks mikrokosmos, Morris dan Dewey (Zais dan Robert,1976:106)

Kandungan tujuan dan target KKM berbasis PAR harus dipahami secara arif oleh para pelaku pendidikan. Ia bukan hanya subject matter, melainkan ia dapat mewarnai misi, arah dan tujuan peserta didik dalam proses pengajaran. Dari perspektif pendidikan umum, ialah diharapkan tercapainya internalisasi nilai-nilai, sehingga manusia dapat memahami keberadaan dirinya sebagai manusia yang memiliki ciri khas dan karakteristik tersendiri dibanding dengan makhluk lain. Di samping ia mampu mewariskan nilai-nilai tersebut dengan tujuan adanya perubahan sikap dan perilaku baik perubahan pada dirinya maupun pada orang lain. Juga yang mempengaruhi kurikulum ialah: (a) masyarakat dan kebudayaan, (b) filosofi hidup seseorang dan (d) teori belajar. Dalam konteks proses belajar mengajar berlangsung, yang dimaksud masyarakat dan kebudayaan ialah lingkungan di mana terdapat kemajemukan sikap, pengetahuan, kepercayaan, kesenian, hukum, adat istiadat dan kebiasaankebiasaan lainnya ialah akan mempengaruhi kandungan kurikulum yang telah, sedang dan akan diberdayakan oleh suatu lembaga pendidikan atau oleh seseorang. Sementara Ahmad Tafsir (2006:224-225) telah menawarkan metode internalisasi, yakni: (1) Tahu, mengetahui (knowing). Di sini tugas guru ialah mengupayakan agar murid mengetahui sesuatu konsep, (2) Mampu melaksanakan atau mengerjakan yang ia ketahui itu (doing), (3) Murid menjadi orang seperti yang ia ketahui itu. Konsep itu seharusnya tidak sekedar menjadi miliknya tetapi menjadi satu dengan kepribadiannya.

\section{b. Bahan Ajar}

Bahan ajar workshop KKM berbasis PAR ialah memadukan teori dengan praktek sebelum para mahasiswa terjun ke masyarakat. Bahan ajar ini seperti: Teknik observasi dan field note, Pendidikan kritis dan metodologi riset/ pengabdian transformatif, Pendidikan emansipatorik/popular, Being researcher for PAR, Persiapan ke lapangan: teknik-teknik PRA (Wawancara, diskusi kelompok terarah, social mapping, diagram venn dan diagram alur), Being fasilitator, Teknik time line dan teknik Trend and change, Teknik daily routine dan kalender musim, Analisis matrik ranking, Analisis pohon masalah dan analisis tujuan, Studi praktek ke lapangan, Presentasi setiap kelompok dari hasil studi lapangan, Analisis partisipasi, dan Matrik perencanaan operasional (MPO) dan matrik rencana kerja (MRK). Berdasarkan analisis isi bahan ajar workshop KKM berbasis 
PAR ditemukan bahwa bahan ajar yang disajikan dalam proses pembelajarannya ialah lebih banyak diarahkan pada cara berpikir kritis dan konstruktifis, tidak ada pembahasan dan upaya penggalian atas muatan tata-nilai atau maknamakna moral sebagai manifestasi pembelajaran internalisasi nilai kerjasama sebagai salah satu bentuk nilai sosial.

\section{c. Metode Pembelajaran}

Metode pembelajaran dalam KKM berbasis PAR di IAIN Syekh Nurjati Cirebon, ialah deskripsi rangkaian kegiatan yang dilalui mahasiswa peserta pengabdian masyarakat sejak persiapan, pelaksanaan dan evaluasi. Pada saat mahasiswa mengikuti workshop persiapan KKM berbasis PAR, metode pembelajaran yang sering dijumpai dan dilakukan para dosen pembimbing lapangan (DPL) ialah (1) ceramah, isinya: DPL menjelaskan bahan ajar KKM seperti: konsep dasar PAR, langkahlangkah PAR, teknik observasi dan field note, teknik time line dan teknik Trend and change, teknik daily routine dan kalender musim, analisis matrik ranking, analisis pohon masalah dan analisis tujuan, analisis partisipasi; (2) Focus Group Discussion, membahas bahan ajar dimaksud dengan cara kerjasama satu sama lain; (3) Praktek, mahasiswa melakukan mini observasi lapangan sebagai upaya mempraktekan bahan ajar PAR di luar dan atau di dalam kampus; (4) Demonstrasi, mahasiswa mempresentasikan hasil mini observasi PAR di hadapan sesama mahasiswa dan DPL yang dilanjutkan dengan peer feedback dan refleksi.

Pada saat pelaksanaan KKM berbasis PAR, mahasiswa melakukan proses pembelajaran melalui langkah-langkah: observasi (pengenalan lingkungan, menemukan contact person), (2) persiapan sosial. Terlibat secara langsung dalam kehidupan masyarakat; (3) mapping masalah sosial; (4) identifikasi data, fakta sosial. Mengamati dan mengidentifikasi fakta-fakta sosial (baik verbal maupun non verbal/simbol-simbol), biasanya muncul sebagai keluhan dan kegelisahan yang sering dibicarakan masyarakat; (5) analisa sosial (struktural).

Mendiskusikan/mengurai fakta-fakta untuk menemukan isu sosial. Mempertanyakan terus menerus, mengapa masalah itu terjadi, bagaimana pola relasi sosial yang ada. Menilai posisi masyarakat dalam peta hubungan-hubungan antar kelompok masyarakat tersebut; (6) menentukan prioritas perumusan masalah sosial; (7) mengatur gagasan-gagasan yang muncul guna mencari peluang-peluang yang mungkin bisa dilakukan bersama guna memecahkan masalah dengan memperhatikan pengalamanpengalaman masyarakat dimasa lalu (keberhasilan dan kegagalannya); (8) pengorganisasian sumber daya, dengan mengidentifikasi siapa yang harus diajak bekerjasama dan siapa yang akan menghambat; melakukan aksi dan (10) refleksi.

Metode-metode dan langkahlangkah pembelajaran KKM berbasis PAR tersebut sebenarnya dapat menjadi media pembelajaran nilai dan atau bisa disisipkan pendekatan analisis. Dasar pemikiran dari pendekatan analisis terhadap nilainilai pendidikan terletak pada membantu peserta didik mengembangkan berpikir logis dan menggunakan prosedur penyelidikan 
ilmiah dalam memecahkan isu-isu nilai. Selain itu, Analisis nilai berupaya untuk membantu peserta didik mengembangkan nilai-nilai mereka sendiri sebagai tanggapan terhadap konflik-konflik nilai dalam masyarakat. Menurut Superka (1975:24-25), pendekatan analisis memandang manusia sebagai makhluk rasional yang bisa mencapai kebaikan tertinggi dengan menundukkan perasaan dan gairah terhadap logika dan metode ilmiah. Hanya dengan perasaan pribadi orang bisa memecahkan masalah nilai sesuai dengan logika dan sains. "Dasar filosofis pendekatan analisis ... tampaknya merupakan fusi dari rasionalis dan empiris dalam melihat sifat manusia." Oleh karena itu, dasar pemikiran dari pendekatan analisis melibatkan pengembangan berpikir logis dan penggunaan metode ilmiah, sehingga peserta didik dapat berpartisipasi dan meresolusi konflik terbuka antara berbagai kelompok dalam masyarakat. Resolusi tersebut dianggap sebagai hal penting untuk kelangsungan hidup sebuah masyarakat bebas dan demokratis.

d. Sarana, Alat atau Instrumen Pembelajaran.

Secara umum, instrument pembelajaran internalisasi nilai dalam KKM berbasis PAR ialah merujuk pada: (1) Panduan Teknis Pelaksanaan KKM, yang diterbitkan oleh P3M IAIN Syekh Nurjati Cirebon, memuat: pendahuluan, hak dan kewajiban peserta KKM, hak dan kewajiban DPL KKM, mengenal metodologi PAR dan Rapid Rural Appraisal; (2) Buku pendamping pengabdian kepada masyarakat/ penelitian bersama masyarakat, memuat konsep dasar PAR; dan (3) buku field note, memuat lembaran kosong yang harus diisi calon peserta KKM pada setiap sesi.

Ketiga instrumen pembelajaran internalisasi nilai tersebut keseluruhannya menghadirkan uraian riset kritis dalam studi islam secara akademik melalui focus group discussion, tanpa sedikit pun mengurai dimensi akhlak sosial di lihat dari segi afektif. Artinya, sarana dan instrumen pembelajaran internalisasi nilai yang digunakan mengalami kelemahan, karena belum mengarah pada penggunaan instrumen atau sarana pembelajaran internalisasi nilai yang berbasis pada pembelajaran afektual. Menurut Krathwohl (1964) dalam Rupchenko, Ian; Parsons, Jim (1987:2) tujuan utama penanaman nilai adalah untuk mensosialisasikan peserta didik pada nilai sehingga nilai-nilai sosial, moral, politik atau nilai-nilai budaya terinternalisasi. Peserta didik tidak hanya didorong untuk membuat pilihan bebas, tapi untuk bertindak sesuai dengan nilai-nilai yang ditentukan sebelumnya. Dari sudut pandang pendekatan penanaman nilai, menghargai dianggap sebagai suatu proses identifikasi dan sosialisasi. Seorang individu, kadang-kadang tidak sadar, adalah ditanamkan dengan standar atau norma orang lain, kelompok, atau masyarakat. Harapannya bahwa nilai-nilai ini bersatu ke dalam sistem nilai yang dimiliki seseorang. Nilai, dari perspektif ini, biasanya disusun untuk menjadi standar atau aturan perilaku yang bersumber dari masyarakat atau budaya.

\section{e. Evaluasi}

Dan diakhiri dengan evaluasi yang dilakukan melalui penilaian laporan KKM dan ujian hasil KKM berbasis PAR. Evaluasi terhadap mahasiswa meliputi: (a) penilaian akademik; aspek kemampuan, 
metodologi pengabdian masyarakat, aktifitas di lokasi dan ujian KKM; (b) keikutsertaan mengikuti kegiatan workshop, (c) kemampuan merumuskan materi diklat, (d) kegiatan penelitian, (e) keterampilan memecahkan masalah,

kemampuan melaksanakan program, (g) kedisiplinan, (h) kerjasama, (i) integrasinya dengan masyarakat. Di sini ada potensi pengembangan pendidikan nilai, yakni penilaian peserta KKM dari segi kedisiplinan, kerjasama dan integrasinya dengan masyarakat. Yang menjadi masalah ialah instrumen penilaian afektif belum terformulasikan secara akademik.

\section{Temuan Nilai Kerjasama: salah satu Nilai Sosial}

Kerjasama adalah proses interaksi peserta didik dengan pendidik dan sumber belajar pada suatu lingkungan belajar dan juga di masyarakat. Pembelajaran merupakan bantuan yang diberikan pendidik agar dapat terjadi proses pemerolehan ilmu dan pengetahuan, penguasaan kemahiran dan tabiat, serta pembentukan sikap dan kepercayaan pada peserta didik. Dengan kata lain, pembelajaran adalah proses untuk membantu peserta didik agar dapat belajar dengan baik. Kaitan dengan nilai kerjasama sebagai salah satu nilai sosial mahasiswa pada KKM berbasis PAR, ialah rumusan proses pembelajaran sosial yang di alami mahasiswa sebagai peserta program di masyarakat. Sejak ia mengikuti fase persiapan, yakni saat mengikuti workshop, pelaksanaan KKM dan pada saat di akhir kegiatan KKM.

Realitas kerjasama mahasiswa pada KKM berbasis PAR ialah lebih menitikberatkan pada kerjasama program pendampingan atau mendampingi program bersama masyarakat. Sedangkan alat atau instrumen untuk mendampingi masyarakat dalam mengidentifikasi potensi, peluang dan hambatan proses pembangunan masyarakat ialah: catatan lapangan atau fieldnote, wawancara semi terstruktur, pemetaan, penelusuran wilayah, diagram venn-hubungan kelembagaan, alur sejarah, kalender musim, trend and change, kegiatan harian, diagram alur, matriks ranking, action plan, pohon masalah, pohon tujuan, hirarki analisa tujuan, matrik analisis partisipasi, matriks perencanaan operasional (MPO) atau matrik rencana kerja (MRK). Kedudukan mahasiswa pada saat mendampingi program bersama masyarakat ialah berfungsi sebagai fasilitator. Fungsi dan peran fasilitator ialah menjamin bahwa setiap peserta mempunyai kesempatan untuk memberikan sumbangan pada sebuah diskusi, dan nilai-nilai dalam memfasilitasi ialah: demokrasi, tanggung jawab, kerjasama, kejujuran dan kesamaan derajat.

Mahasiswa sebagai fasilitator memiliki etika yang diemban, yakni: jangan menjadi superman, jangan menjadi manipulator, bukan seorang psikolog, tidak diskriminatif, bukan penyelesai masalah dan bukan milik perorangan. Sedangkan ciri-ciri sikap seorang fasilitator ialah: saling belajar dan saling menghargai, bersikap sederajat dan akrab, mendengarkan dan tidak mendominasi, tidak menggurui, tidak memihak dan tidak mengkritik secara frontal, bersikap terbuka dan rendah hati, bersikap positif, selalu melakukan kontak mata dengan peserta dan memperhatikan peserta yang paling diam (sumber: panduan teknis pelaksanaan KKM ke 16, 2009:112113).

Nilai-nilai dimaksud, yakni: (1) nilai individu, (2) nilai budaya, (3) nilai sosial dan (4) nilai kerja. Nilai-nilai sosial (social values) ialah ... as standards or rule of a society", Kniker 
(1977:30) atau ... are set of society attitude considered as a truth and it is become the standard for people to act in order to achieve democratic and harmonious life", Raven (1977: 220). Nilai-nilai sosial merupakan seperangkat sikap masyarakat yang dipandang benar dan menjadi standar tingkah laku seseorang guna memperoleh kehidupan demokratis dan harmonis.Nilai-nilai ini seperti: loves,kasih sayang yakni: pengabdian, tolong-menolong, kekeluargaan, kesetiaan, dan kepedulian; (2) responsibility, tanggung jawab yakni: disiplin, dan empati; dan (3) life harmony, keserasian hidup, yakni:adil, toleran, kerjasama, dan demokratis. Raven (1977: 221-227)

Di lihat dari segi proses kegiatan KKM berbasis PAR, kegiatan-kegiatan sosial yang dilakukan ialah jauh berbeda dengan kegiatan-kegiatan KKM sebelumnya seperti, satu segi mereka berpartisipasi dalam kegiatan desa yang meliputi; Kerja bakti, mengikuti rapat-rapat di lembaga desa, karang taruna, posyandu, majlis ta'lim, dll. Berpartisipasi aktif dalam kegiatan kemasjidan yang di programkan seperti; menjadi khotib jum'at, mengisi pengajian, mengajar di MD/TK/MI, tadarusan, dll. Segi lain, mahasiswa melakukan proses pendampingan terhadap masyarakat melalui instrument-instrumen PAR dan lebih berorientasi pada melatih keterampilan berpikir atau the skills of thinking dari pada keterampilan social. Joyce, Bruce R (1986:420) menyatakan ... the core of good thinking is the ability to solve problems. The essence of problem solving is the ability to learn in puzzling situations. Semua nilai-nilai dimaksud ialah secara esensi dan atau filosofis dalam konteks pelaksanaan KKM berbasis PAR, sangat dipengaruhi oleh konsep dasar PAR itu sendiri disamping memiliki makna universal dalam perspektif Pendidikan Umum/Nilai, sebagaimana tertera pada Tabel berikut:

TABEL 1

NILAI-NILAI YANG TERKANDUNG

DALAM KEGIATAN KULIAH KERJA MAHASISWA BERBASIS PARTICIPATORY ACTION RESEARCH

\begin{tabular}{|c|c|c|}
\hline $\begin{array}{l}\text { KEGIATAN } \\
\text { KULIAH KERJA } \\
\text { MAHASISWA } \\
\end{array}$ & $\begin{array}{l}\text { PARTICIPATOR } \\
\text { Y ACTION } \\
\text { RESEARCH } \\
\end{array}$ & $\begin{array}{l}\text { PENDIDIKAN } \\
\text { UMUM/NILAI }\end{array}$ \\
\hline \multicolumn{3}{|l|}{ a. Persiapan } \\
\hline \multicolumn{3}{|l|}{$\begin{array}{c}\text { Kegiatan } \\
\text { workshop }\end{array}$} \\
\hline $\begin{array}{c}1 . \\
\text { materi }\end{array}$ & Partisipatoris & $\begin{array}{l}\text { Belajar } \\
\text { menghargai } \\
\text { pendapat }\end{array}$ \\
\hline $\begin{array}{cc}2 . & \text { Tugas } \\
\text { individu }\end{array}$ & Partisipatoris & Self-disciple \\
\hline $\begin{array}{l}\text { 3. Tugas } \\
\text { kelompok } \\
\text { membuat } \\
\text { social } \\
\text { mapping, } \\
\text { diagram } \\
\text { venn, } \\
\text { diagram } \\
\text { alur, time } \\
\text { line, Trend } \\
\text { and } \\
\text { change, } \\
\text { daily } \\
\text { routine, } \\
\text { kalender } \\
\text { musim, } \\
\text { Analisis } \\
\text { matrik } \\
\text { ranking, } \\
\text { Analisis } \\
\text { pohon } \\
\text { masalah, } \\
\text { analisis } \\
\text { tujuan, } \\
\text { Analisis } \\
\text { partisipasi, } \\
\text { Matrik } \\
\text { perencanaa } \\
\text { n } \\
\text { operasional } \\
\text { (MPO) dan } \\
\text { matrik } \\
\text { rencana } \\
\text { kerja } \\
\text { (MRK). } \\
\end{array}$ & $\begin{array}{l}\text { Partisipatoris, } \\
\text { kritis, } \\
\text { kolaboratif, } \\
\text { transformatif }\end{array}$ & $\begin{array}{l}\text { Kerjasama, } \\
\text { tanggungjawab, } \\
\text { self-discipline } \\
\text { and group- } \\
\text { discipline, belajar } \\
\text { menghargai dan } \\
\text { menerima } \\
\text { pendapat teman }\end{array}$ \\
\hline $\begin{array}{ll}4 . & \text { Diskusi } \\
\text { kelompok }\end{array}$ & $\begin{array}{l}\text { Partisipatoris, } \\
\text { kolaboratif, } \\
\text { Kritis }\end{array}$ & $\begin{array}{l}\text { Kerjasama, } \\
\text { tanggung jawab, } \\
\text { ketrampilan } \\
\text { berpikir, self- } \\
\text { discipline and } \\
\text { group-discipline }\end{array}$ \\
\hline $\begin{array}{c}\text { 5. Menyepakati } \\
\text { mekanisme } \\
\text { diskusi }\end{array}$ & Partisipatoris & $\begin{array}{l}\text { Kerjasama, } \\
\text { loyalitas }\end{array}$ \\
\hline $\begin{array}{cc}6 . & \text { Menjadi } \\
\text { penyaji } & \end{array}$ & $\begin{array}{l}\text { Partisipatoris, } \\
\text { kritis }\end{array}$ & $\begin{array}{l}\text { Keberanian, } \\
\text { keterampilan } \\
\text { berpikir, self- } \\
\text { discipline }\end{array}$ \\
\hline Menjadi & Partisipatoris & Kerjasama, \\
\hline
\end{tabular}




\begin{tabular}{|c|c|c|}
\hline $\begin{array}{l}\text { penunjang } \\
\text { diskusi }\end{array}$ & & loyalitas \\
\hline $\begin{array}{l}\text { 8. Menanggapi } \\
\text { diskusi }\end{array}$ & $\begin{array}{l}\text { Partisipatoris, } \\
\text { kritis }\end{array}$ & $\begin{array}{l}\text { Kepedulian, } \\
\text { responsive, } \\
\text { belajar } \\
\text { menghargai }\end{array}$ \\
\hline $\begin{array}{l}9 . \\
\text { mendominasi }\end{array}$ & Partisipatoris & Self-discipline \\
\hline $\begin{array}{l}\text { 10. Menghargai } \\
\text { pendapat }\end{array}$ & Partisipatoris & $\begin{array}{l}\text { Love of peace, } \\
\text { mercy } \\
\text { compassionate }\end{array}$ \\
\hline $\begin{array}{l}\text { 11.Membahas } \\
\text { pertanyaan }\end{array}$ & $\begin{array}{l}\text { Partisipatoris, } \\
\text { kritis }\end{array}$ & $\begin{array}{l}\text { Ketrampilan } \\
\text { berpikir, } \\
\text { kejujuran }\end{array}$ \\
\hline Mini Observasi & $\begin{array}{l}\text { Partisipatoris, } \\
\text { kritis, } \\
\text { transformatif }\end{array}$ & $\begin{array}{l}\text { Kerjasama, } \\
\text { Ketrampilan } \\
\text { social, } \\
\text { ketrampilan } \\
\text { berpikir, self- } \\
\text { discipline }\end{array}$ \\
\hline $\begin{array}{l}\text { Presentasi } \\
\text { individual }\end{array}$ & $\begin{array}{l}\text { Partisipatoris, } \\
\text { kritis, } \\
\text { transformatif }\end{array}$ & $\begin{array}{l}\text { Keberanian, } \\
\text { kejujuran, self- } \\
\text { discipline }\end{array}$ \\
\hline \multicolumn{3}{|l|}{ b. Pelaksanaan } \\
\hline $\begin{array}{l}\text { 1. Bersama } \\
\text { masyarakat } \\
\text { membuat } \\
\text { social } \\
\text { mapping, } \\
\text { diagram venn, } \\
\text { diagram alur, } \\
\text { Teknik time } \\
\text { line, Trend } \\
\text { and change, } \\
\text { daily routine, } \\
\text { kalender } \\
\text { musim, } \\
\text { Analisis matrik } \\
\text { ranking, } \\
\text { Analisis pohon } \\
\text { masalah, } \\
\text { analisis tujuan, } \\
\text { Analisis } \\
\text { partisipasi, } \\
\text { Matrik } \\
\text { perencanaan } \\
\text { operasional } \\
\text { (MPO) dan } \\
\text { matrik rencana } \\
\text { kerja (MRK). }\end{array}$ & $\begin{array}{l}\text { Partisipatoris, } \\
\text { praktek sosial, } \\
\text { kolaboratif, } \\
\text { emansipatoris, } \\
\text { kritis, reflektif } \\
\text { dan } \\
\text { transformatif. }\end{array}$ & $\begin{array}{l}\text { Kerjasama, } \\
\text { emphati, peduli, } \\
\text { kepekaan social, } \\
\text { kesetaraan, } \\
\text { kemitraan, tolong } \\
\text { menolong, } \\
\text { kekeluargaan, } \\
\text { menghargai dan } \\
\text { mau menerima } \\
\text { pendapat } \\
\text { masyarakat, } \\
\text { keterbukaan, } \\
\text { toleran, tanggung } \\
\text { jawab social, } \\
\text { peace lover, self- } \\
\text { discipline dan } \\
\text { demokrasi. }\end{array}$ \\
\hline $\begin{array}{l}\text { 2. Pengabdian } \\
\text { masyarakat }\end{array}$ & $\begin{array}{l}\text { Partisipatoris, } \\
\text { kritis, } \\
\text { Transformatif }\end{array}$ & $\begin{array}{l}\text { Kerjasama, } \\
\text { tanggung jawab, } \\
\text { self-discipline }\end{array}$ \\
\hline $\begin{array}{l}\text { 3. Fasilitator } \\
\text { dan } \\
\text { pendampin } \\
\text { g } \\
\text { masyarakat }\end{array}$ & $\begin{array}{l}\text { Partisipatoris, } \\
\text { praktek sosial, } \\
\text { kolaboratif, } \\
\text { emansipatoris, } \\
\text { kritis, reflektif } \\
\text { dan } \\
\text { transformatif. }\end{array}$ & $\begin{array}{l}\text { Nilai Etis: tidak } \\
\text { menjadi } \\
\text { superman, tidak } \\
\text { menjadi } \\
\text { manipulator, } \\
\text { bukan seorang } \\
\text { psikolog, tidak } \\
\text { diskriminatif, } \\
\text { bukan penyelesai } \\
\text { masalah dan } \\
\text { bukan milik } \\
\text { perorangan. } \\
\text { Sikap: Saling } \\
\text { belajar dan saling } \\
\text { menghargai, } \\
\text { bersikap sederajat } \\
\text { dan akrab, } \\
\text { mendengarkan } \\
\text { dan tidak } \\
\text { mendominasi, }\end{array}$ \\
\hline
\end{tabular}

\begin{tabular}{|c|c|c|}
\hline & & $\begin{array}{l}\text { tidak menggurui, } \\
\text { tidak memihak } \\
\text { dan tidak } \\
\text { mengkritik secara } \\
\text { frontal, terbuka } \\
\text { dan rendah hati, } \\
\text { bersikap positif, } \\
\text { selalu melakukan } \\
\text { kontak mata } \\
\text { dengan dan } \\
\text { masyarakat datikan } \\
\text { memperhatikan } \\
\text { masyarakat yang } \\
\text { paling diam. }\end{array}$ \\
\hline $\begin{array}{l}\text { 4. Workshop } \\
\text { tingkat Desa }\end{array}$ & Partisipatoris & $\begin{array}{l}\text { Kerjasama, } \\
\text { tanggung jawab, } \\
\text { self-discipline } \\
\text { and group- } \\
\text { discipline }\end{array}$ \\
\hline $\begin{array}{l}5 . \quad \text { Workshop } \\
\text { tingkat } \\
\text { Kecamatan }\end{array}$ & Partisipatoris & $\begin{array}{l}\text { Kerjasama, } \\
\text { tanggung jawab, } \\
\text { self-discipline } \\
\text { and group- } \\
\text { discipline }\end{array}$ \\
\hline $\begin{array}{c}\text { 6. Workshop } \\
\text { tingkat Kabupaten }\end{array}$ & Partisipatoris & $\begin{array}{l}\text { Kerjasama, } \\
\text { tanggung jawab, } \\
\text { self-discipline } \\
\text { and group- } \\
\text { discipline }\end{array}$ \\
\hline \multicolumn{3}{|l|}{ c. Evaluasi } \\
\hline 1. laporan & Partisipatoris & $\begin{array}{l}\text { Self-discipline, } \\
\text { kejujuran }\end{array}$ \\
\hline 2. ujian & $\begin{array}{l}\text { Partisipatoris, } \\
\text { kritis }\end{array}$ & $\begin{array}{l}\text { Self-discipline, } \\
\text { kejujuran, } \\
\text { keberanian }\end{array}$ \\
\hline
\end{tabular}

Internalisasi nilai kerjasama pada Kuliah Kerja Mahasiswa berbasis Participatory Action Research bisa tertanam dari sejak persiapan, pelaksanaan dan evaluasi. Seperti, saat mahasiswa menyimak materi workshop yang disajikan Dosen Pembimbing Lapangan, nilai-nilai partisipatoris dari PAR ikut mendorong tertanamnyainternalized belajar menghargai pendapat orang lain; nilai self-discipline tertanam saat mahasiswa melaksanakan tugas individu; nilai Kerjasama, tanggungjawab, self-discipline and group-discipline, belajar menghargai dan menerima pendapat teman tertanam saat mahasiswa melaksanakan tugas kelompok membuat social mapping, diagram venn, diagram alur, time line, Trend and change, daily routine, kalender musim, Analisis matrik ranking, Analisis pohon masalah, analisis tujuan, Analisis partisipasi, Matrik perencanaan operasional (MPO) dan matrik rencana kerja (MRK); nilai- 
nilai Kerjasama, tanggung jawab, ketrampilan berpikir, self-discipline and group-discipline tertanam saat mahasiswa melaksanakan tugas diskusi kelompok; dan seterusnya. Disinilah pentingnya upaya mengimplementasikan pendekatanpendekatan pembelajaran nilai, sehingga pelaksanaan Kuliah Kerja Mahasiswa berbasis Participatory Action Research lebih terencana, terarah dan bermakna.

\section{Temuan dan Pengembangan Model}

Kuliah Kerja Mahasiswa berbasis Participatory Action Research ialah salah satu bentuk kebijakan sosial kelembagaan IAIN Syekh Nurjati Cirebon dalam rangka mewujudkan Tri Dharma Perguruan Tinggi. Sebuah analisis kebijakan sosial dan usaha terencana berkenaan dengan pemberian penjelasan dan preskripsi atau rekomendasi terhadap konsekuensi-konsekuensi kebijakan sosial yang telah diterapkan, khususnya dalam konteks (1) menemukan indikator-indikator penting nilai-nilai sosial yang dapat dikembangkan melalui KKM berbasis PAR dan faktor-faktor yang berpengaruh terhadap nilai-nilai sosial dan memetakan kerangka model teoritis mengenai upaya pembinaan dan pengembangan nilai-nilai sosial melalui KKM berbasis PAR; (2) merumuskan upaya-upaya yang dapat diterapkan dalam membina dan mengembangkan nilai-nilai sosial melalui KKM berbasis PAR.

Model pembelajaran partisipatif ini menekankan pada proses pembelajaran, di mana kegiatan belajar dalam pelatihan dibangun atas dasar partisipatif (keikutsertaan) peserta pelatihan dalam semua aspek kegiatan pelatihan, mulai dari kegiatan merencanakan, melaksanakan, sampai pada tahap menilai kegiatan pembelajaran. PAR dapat menjadi metode yang sangat efektif dalam melakukan perubahan sosial. Rumusan singkatnya, bahwa keberhasilan pembangunan ialah mendasarkan atas prinsip-prinsip: (1)
Partisipasi rakyat dalam menentukan/memutuskan setiap kebijakan pembangunan; (2) Menghormati ilmu pengetahuan lokal, pengalaman praktis mereka dan budaya setempat; (3) Mengangkat ke-swadaya-an rakyat melalui produksi-produksi konsumsi lokal; (4) Mengikuti keragaman sistem ekologi dan mengadaptasikan alternatif-alternatif pemecahan terhadap masalah-masalah ekonomi dan lingkungan; (5) Pendekatanpendekatan yang fleksibel, terpadu, dan multidimensi.

Dengan demikian, pendekatan pemberdayaan (empowering) masyarakat sama sekali berbeda dengan apa yang biasa disebut dengan pendekatan karitatif dan pengembangan masyarakat (community development) yang biasanya berisi pembinaan, penyuluhan, bantuan teknis dan manajemen serta mendorong keswadayaan.

Dalam konteks KKM, pemberdayaan masyarakat tidak berhenti karena KKM telah usai. Di sinilah pentingnya partisipasi. Apalagi, bila hal itu menuju ke riset partisipatoris, sebagai bagian tak terpisahkan dari riset alternatif perguruan tinggi melalui salah satu Tri Dharma-nya. Oleh karenanya PAR untuk KKM merupakan alternatif pendekatan pemberdayaan dan riset di lingkungan IAIN.

\section{Nilai-Nilai Fasilitator:}

Etika: tidak menjadi superman, tidak menjadi manipulator, bukan seorang psikolog, tidak diskriminatif, bukan penyelesai masalah dan bukan milik perorangan.

Sikap: Saling belajar dan saling menghargai, bersikap sederajat dan akrab, mendengarkan dan tidak mendominasi, tidak menggurui, tidak memihak dan tidak mengkritik secara frontal, terbuka dan rendah hati, bersikap positif, selalu melakukan kontak mata dengan masyarakat dan memperhatikan masyarakat yang paling diam. 


\section{SIMPULAN}

Berdasarkan hasil penelitian, dapat dikemukakan beberapa simpulan yaitu :

1. Pada saat pelaksanaan Kuliah Kerja Mahasiswa berbasis Participatory Action Research, mahasiswa melakukan kegiatan-kegiatan, seperti: (1) observasi (pengenalan lingkungan, menemukan contact person), persiapan sosial, terlibat secara langsung dalam kehidupan masyarakat; (3) mapping masalah sosial; (4) identifikasi data, fakta sosial. Mengamati dan mengidentifikasi faktafakta sosial (baik verbal maupun non verbal/simbol-simbol), biasanya muncul sebagai keluhan dan kegelisahan yang sering dibicarakan masyarakat; (5) analisa sosial (struktural). Mendiskusikan/mengurai fakta-fakta untuk menemukan isu sosial. Mempertanyakan terus menerus, mengapa masalah itu terjadi, bagaimana pola relasi sosial yang ada. Menilai posisi masyarakat dalam peta hubungan-hubungan antar kelompok masyarakat tersebut; (6) menentukan prioritas perumusan masalah sosial; (7) mengatur gagasan-gagasan yang muncul guna mencari peluang-peluang yang mungkin bisa dilakukan bersama guna memecahkan masalah dengan memperhatikan pengalamanpengalaman masyarakat dimasa lalu (keberhasilan dan kegagalannya); (8) pengorganisasian sumber daya, dengan mengidentifikasi siapa yang harus diajak bekerjasama dan siapa yang akan menghambat; (9) melakukan aksi dan (10) refleksi.

2. Proses Pembelajaran Kuliah Kerja Mahasiswa berbasis Participatory Action Research telah terjadi proses internalisasi, sebuah proses menanamkan sesuatu, terutama karakteristik PAR itu sendiri yang partisipatoris, praktek sosial, kolaboratif, emansipatoris, kritis, reflektif dan transformatif. Sedangkan internalisasi nilai-nilai kerjasama adalah sebuah proses menanamkan nilai-nilai kerjasama. Pada konteks PAR atau Riset Aksi Partisipatoris yang merupakan riset yang memfokuskan diri pada pengaruh aksi dari praktek dalam sebuah komunitas partisipatoris dengan tujuan meningkatkan mutu kinerja komunitas atau suatu area perhatian. Riset Aksi melibatkan pemanfaatan suatu metoda perencanaan siklis sistematis, pengambilan tindakan, pengamatan, evaluasi (mencakup evaluasi diri) dan refleksi kritis sebelum perencanaan siklus berikutnya. Tindakan mempunyai seperangkat tujuan menujukan suatu masalah yang teridentifikasi di dalam tempat kerja. Ini merupakan suatu metoda kolaboratif untuk menguji gagasan baru dan menerapkan aksi untuk perubahan. Itu melibatkan keikutsertaan langsung di dalam sebuah proses riset dinamis, sedangkan monitoring dan evaluasi terhadap efek tindakan peneliti dengan tujuan meningkatkan praktek. Internalisasi kerjasama pada KKM berbasis PAR terlihat pada caranya yang bertujuan untuk meningkatkan pemahaman bagaimana perubahan dalam aksi seseorang atau praktek seseorang dapat satu sama lain bermanfaat bagi suatu masyarakat praktisi. PAR adalah sebuah pendekatan yang relatif baru dan kolaboratif dalam riset aksi dan PAR merupakan riset aksi generasi keempat yang harus memperjuangkan emansipasi dan transformasi pendidikan dengan cara melakukan kerjasama dengan orang lain untuk merubah praktek sosial yang ada dan dengan penggunaan refleksi kritis dan kritik sosial sebagai kunci proses penelitian. Maka PAR adalah kolaboratif, berorientasi pada perubahan dan terbuka secara politis. Pada tahap penerapan PAR oleh peserta KKM, maka PAR dalam teori dan praktek yang berorientasi partisipatif, terbuka 
dan transformatif, dilakukan ketika peserta KKM melakukan persiapan, pelaksanan dan tahap evaluasi (pasca melakukan KKM). Situasi kerjasama yang dibangun adalah berkaitan antara peserta KKM, masyarakat, stakeholder dan juga institusi (IAIN Syekh Nurjati Cirebon) yang memegang peranan penting dalam memberikan basis keilmuan dan orientasi pengabdian yang berbasis aksi partisipatoris. Situasi yang terjadi pada proses internalisasi kerjasama pada KKM berbasis PAR ialah pada saat mahasiswa melakukan Mapping, Seasonal Calender, Diagram Venn, Time Line, Trend and Change, Matrix rangking dan Diagram alur sehingga situasi pembelajaran menjadi dinamis, partisipatif dan kolaboratif. Esensi pendekatan-pendekatan pembelajaran nilai menjadi sangat penting posisinya untuk mensosialisasikan peserta didik pada nilai sehingga nilai-nilai sosial, moral, politik atau nilai-nilai budaya terinternalisasi. Peserta didik tidak hanya didorong untuk membuat pilihan bebas, tapi untuk bertindak sesuai dengan nilai-nilai yang ditentukan sebelumnya. Dari sudut pandang pendekatan penanaman nilai, menghargai dianggap sebagai suatu proses identifikasi dan sosialisasi. Seorang individu, kadang-kadang tidak sadar, adalah ditanamkan dengan standar atau norma orang lain, kelompok, atau masyarakat. Harapannya bahwa nilai-nilai ini bersatu ke dalam sistem nilai yang dimiliki seseorang. Nilai, dari perspektif ini, biasanya disusun untuk menjadi standar atau aturan perilaku yang bersumber dari masyarakat atau budaya. Pendekatan Pengembangan moral adalah untuk merangsang para peserta didik untuk mengembangkan kekuatan alasan moral mereka melalui serangkaian tahapan semakin canggih dan kompleks. Tujuan perkembangan moral bukan sebagai peningkatan pengetahuan peserta didik tentang nilainilai budaya maupun menanamkan sebuah nilai eksternal pada peserta didik, tetapi lebih sebagai pendorong pola nilai terhadap peserta didik. Pendekatan analisis memandang manusia sebagai makhluk rasional yang bisa mencapai kebaikan tertinggi dengan menundukkan perasaan dan gairah terhadap logika dan metode ilmiah. Hanya dengan perasaan pribadi orang bisa memecahkan masalah nilai sesuai dengan logika dan sains. Pendekatan emosional-rasional berbeda dari pembelajaran aksi yang menekankan perasaan atau sisi emosional daripada sisi rasional dari sifat manusia. Pendekatan ini tidak menolak rasionalisme, juga tidak menganjurkan ekspresi yang terkendali emosi. Sebaliknya, manusia lebih dilihat sebagai makhluk perasaan daripada mesin penalaran. Orang menciptakan dengan lingkungan mereka, tetapi dalam pendekatan emosional- rasional bukan hanya dalam cara yang rasional.

3. Kuliah Kerja Mahasiswa berbasis Participatory Action Research di IAIN Syakh Nurjati Cirebon merupakan upaya untuk memadukan antara pengabdian yang berbasis riset aksi dan kesadaran masyarakat. Pada konteks perubahan paradigmatik, KKM dapat menjadi studi alternatif bagi penelitian Islam dan pemberdayaan untuk perubahan masyarakat dengan tetap menghargai budaya lokal. Berikutnya masyarakat mampu melakukan upaya percepatan pengembangan sumber daya manusia dan pemanfaatan sumber daya alam untuk perubahan sosial dan ekonomi sesuai dengan budaya setempat. Melakukan perubahan paradigmatik dalam penyelenggaraan KKM, yakni dari KKM konvensional kearah riset Islam dan pemberdayaan masyarakat yang partisipatif. 


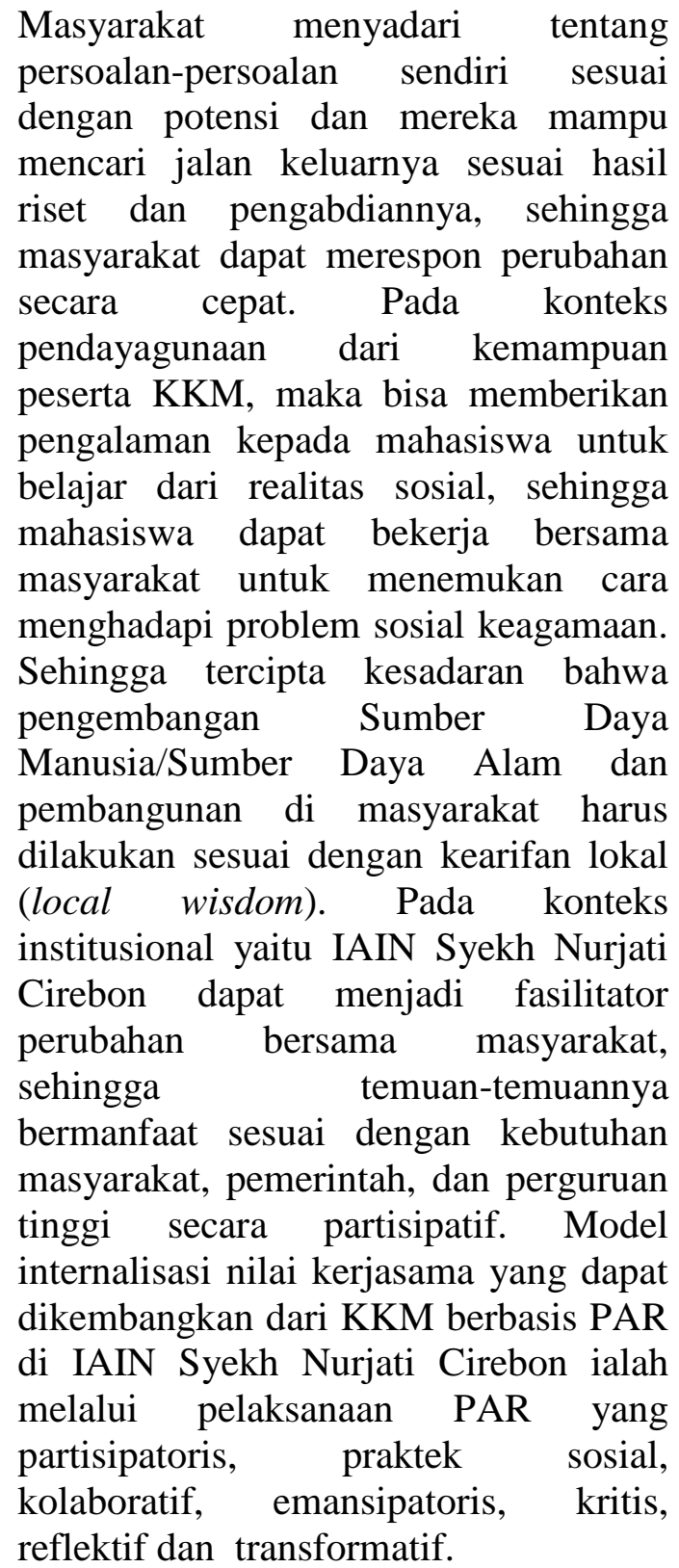

\section{Rekomendasi}

Pertama, rekomendasi mengenai pendalaman dan penghayatan tentang kesadaran akan pentingnya insan akademis terhadap cara pandang dalam memajukan masyarakat melalui beberapa kegiatan akademik. Selama ini pengabdian yang diberikan oleh kepentingan institusional lebih banyak bermuatan satu arah, monolitik, monolog dan bersifat tentatif. Padahal dengan perkembangan zaman, pengabdian yang disponsori oleh sebuah institusi seharusnya memberikan dampak dalam masyarakat menuju situasi yang tercerahkan, kesadaran akan kepentingan masyarakat dan membiarkan masyarakat menata kehidupannya. Oleh karena itu, untuk memberikan dampak pengabdian kepada masyarakat yang lebih humanis dan inklusif, maka pada akademisi dan praktisi sosial sudah saatnya mengubah mind set dari developmentalisme menuju arah pengabdian yang partisipatif dan emansipatoris.

Kedua, rekomendasi untuk penelitian lanjutan. Alur masyarakat yang selalu berubah menunjukkan bahwa nilai-nilainya juga selalu harus ada interpretasi dan dialog dengan realitas. Dengan demikian, masyarakat yang dalam logika mereka, mesti diberikan perhatian khusus bukan sebagai obyek namun merupakan subyek yang senantiasa berkembang. Perkembangan riset dalam mendekati dan mendalami kecenderungan realitas masyarakat, mengalami perubahan paradigma sesuai dengan time-spacenya. Ini merupakan perkembangan yang berbasis pada pemaduan antara kepentingan teori keilmuan dan implementasi pada tataran realitas yang berdasar pada perkembangan masyarakat yang harmonis, inklusif, partisipatif dan transformatif. Oleh karena itu tawaran adanya perubahan paradigm pada bentuk riset terhadap perkembangan masyarakat merupakan das solen dan das sein yang harus berimbang. Maka Panduan sivitas tentang penerapan model yang mencakup penentuan masing-masing kompetensi, langkah-langkah pembelajaran, serta bahan ajar yang sesuai, sangat diperlukan dalam pengembangan model pembelajaran internalisasi nilai berbasis Participatory Action Research.

\section{DAFTAR PUSTAKA}
Alwasilah,
A.Chaedar.(2009).
Etnopedagogi: Landasan Praktek Pendidikan dan Pendidikan Guru. Bandung: Kiblat Buku Utama.
Aziz,A.M dkk.(2005). Dakwah Pemberdayaan Masyarakat:


Paradigma Aksi Metodologi.

Yogyakarta: PT LkiS Pelangi Aksara.

Atmadi A., Setianingsih Y. (2000).

Transformasi Pendidikan: Memasuki

Milenium Ketiga. Yogyakarta:

Universitas Sanata Dharma.

Baidhawy, Zakiyudin. (2005). Pendidikan

Agama Berwawasan Multikultural.

Jakarta: Erlangga.

Banks, James A. (1990). Teaching Strategies for the Social Studies: Inquiry, Valuing, and DecisionMaking. New York \& London: Longman.

Bloom,BS., Hastinga,JT. And Madaus, GF. (1971). Handbook of Formative and Summative Evaluation of Student Learning. New York: McGraw-Hill Books.

Bogdan \& Biklen. (1992). Qualitative Research for Education: An Introduction to Theory and Methods. America: Allyn and Bacon.

Bord, Walter R. (1983). Educational Research: An Introduction. New York \& London: Longman.

Brubacher. (1950). Modern Philosophies of Education. New York: McGrawHill Book Company, Inc.

Burn, Robert B. (1995). Introduction to Research Methods. Australia: Longman Australia Pty Ltd.

Bartal, D., (1976). Prosocial Behavior: Theory and Reseach. Washington D.C.: Hemisphere Publishing Co.

Bachri, S.A. (2004). Implementasi Nilai Moral Budaya Sunda dalam Visi dan Misi Perguruan Tinggi Swasta di Jawa Barat. Disertasi Doktor pada PPS IKIP Bandung: tidak diterbitkan.

Cartledge, G. and Milburn, J.F. (1992). Teaching Social Skill to Children: Innovative Approach. New York: Pergamon Press.

Cahyono. B.Y. (2006). Metode Pendekatan Sosial Dalam Pembangunan Partisipatif. [Online]. Tersedia:
http://lppm.petra.ac.id/ppm/COP/dow nload [2 November 2007].

Chadwick, Bruce A. (1984). Metode Penelitian Ilmu Sosial. Penerjemah Sulistia dkk. New Jersey: IceHal,Inc.

Conrad Phillip Kottak. (2010).

Enculturation [Online]. Tersedia:

http://en.wikipedia.org/wiki/

Enculturation [10 Januari 2010].

Djahiri,A.Kosasih. (1995). Dasar-Dasar Umum Metodologi dan Pengajaran Nilai-Moral:PVCT. Bandung: Laboratorium Pengajaran PMP IKIP Bandung.

Departemen Sosial R.I. (2007). Model Pelatihan Berdasar Pada Subject Matter. Analysis [Online]. Tersedia: http://www.depsos.go.id [9 Agustus 2007].

Departemen Pendidikan dan Kebudayaan. (1983).Keputusan Direktur Jenderal Pendidikan Tinggi Departemen Pendidikan dan Kebudayaan RI Nomor 48/DJ/Kep/1983 tentang Beban Tugas Tenaga Pengajar pada Perguruan Tinggi Negeri. Jakarta: Depdikbud.

Departemen Pendidikan Nasional. (2006). Keputusan Direktur Jenderal Pendidikan Tinggi Departemen Pendidikan Nasional RI Nomor: 43/DIKTI/Kep/2006 tentang Ramburambu pelaksanaan Kelompok Matakuliah Pengembangan Kepribadian di Perguruan Tinggi. Jakarta: Depdiknas. . (2006). Keputusan Direktur Jenderal Pendidikan Tinggi Departemen Pendidikan Nasional RI Nomor: 44/DIKTI/Kep/2006 tentang Rambu-rambu pelaksanaan Kelompok Matakuliah Berkehidupan Bermasyarakat di Perguruan Tinggi.Jakarta: Depdiknas . (2003). UU No.20 Tahun 2003 tentang Sistem Pendidikan Nasional. Jakarta: Depdiknas 
Departemen Agama. (1998). Al-Qur'an dan Terjemahnya. Semarang: CV. Asy-syifa.

Ellis, Arthur K. (1998). Teaching and Learning Elementary Social Studies. America: Allyn \& Bacon, A Viacom Company.

Elliott, John. (1991). Action Research for Educational Change. London: Library of Congress Cataloging-inpublication data.

Elizabeth Dickerson.(1982). Introduction to Social Policy. New York: McGraw-Hill.

Fraenkel ,Jack R. \& Norman E. Wallen. (1990). How to Design and Evaluate Research in Education. New York: McGraw-Hill Publishing Company.

Faridl, M. (2010). "Salat dan Kepedulian Sosial”. Pikiran Rakyat (11 Pebruari 2010).

Fullan, Michael. (1990). The New Meaning of Educational Change. America: Teacher College Press.

Harris CW. (1960). Encyclopedia for Educational Research. New York: Macmillan

Helen, Potts. et al. (1994). Values Strategies for Classroom Teachers. Australia: The Australian Council for Educational Research Ltd.

Hornby,A.S. et al. (1995). Oxford Advanced Learner's Dictionary. London: Oxpord University Press.

Huitt, W. (2004). Values [Online] Tersedia:

http://www.edpsycinteractive.org

/topics /affsys/values.html [ $\quad 8$
Pebruari 2010].

Joyce, Bruce R. (1986). Model of Teaching. New Jersey: Prentice-Hall,Inc.

Kaswardi. (1993). Pendidikan Nilai Memasuki Tahun 2000. Jakarta: Grasindo.

Kipler, Ann, Barbara. (1999). Random House Webster's College Dictionary. Random House,Inc.

Kluckhohn,F.R. dan F.L Stottbect. (1961). Variations in Value Orientation.
New York: Row Peterson and Company.

Koentjaraningrat. (1991). Some Social Anthropological observation on Gotong Royong Practice in Two Village of Central Java. Cornell University

(1991). Metode-Metode Penelitian Masyarakat. Jakarta: PT.Gramedia.

(1986). Pengantar Ilmu Antropologi. Jakarta: Aksara Baru.

Knowles, Malcolm. (1973). The Adult Learner: A Neglected Species. Houston: Gulf Publishing Company.

Kupchenko, Ian; Parson, Jim. (1987). Ways of Teaching Values: An outline of Six Values Approachs. Document Resume Ed 288806.

Kurtines, William M. (1992). Moralitas, Perilaku Moral dan Perkembangan Moral. Penerjemah,M.I. Soelaeman; pendamping,M.D.Dahlan. Jakarta: UI-Press.

Louis G, Locke, (Eds) (1966). Readings for Liberal Education. America: Holt,Rinehart and Winston, Inc.

Mahmudi, A. (2004). Metode Penelitian Kritis dan Prinsip-prinsip Participatory Action Research (PAR). Dalam Jurnal Inovasi Pendidikan Tinggi Agama Islam Swara Ditpertais [Online] No. 19 Th. II, 12 halaman. Tersedia: http://www.ditpertais.net/swara $\quad$ [4 Maret 2009].

Martorella Peter,H., James P. Shaver (Eds) (1991). Handbook of Research on Social Studies, Teaching and Learning. New York: MacMillan Publishing Company.

Marvin C. Alkin, (Eds) (1992). Encyclopedia of Educational Research. New York: Sixth Edition, Volume 2, Macmillan Library Reference USA.

McMillan, James H. (2001). Research in Education. New York: Addison Wesley Longman,Inc. 
Megawangi, Ratna et al. (2005). Pendidikan Holistik. Jakarta: Indonesia Heritage Foundation

McConnel, Henry Nelson B. (1952). The Fifty-First Yearbook of the National Society for the Study of Education. Chicago: The University of Chicago Press.

Meyer E. Adolph. (1949). The Development of Education in the Twentieth Century, Englewood Cliffs, N.J.: Prentice Hall, Inc.

Michael, Yudkin (Eds) (1971). General Education: A Symposium on the Teaching of Non-Specialists. England: Penguin Books.

Moleong, Lexy J. (1988). Metodologi Penelitian Kualitatif. Jakarta: Depdikbud, Dikti.P2LPTK.

Morris, Van Cleve. (1961). Philosophy and the American School. Boston: Houghton Mifflin Company.

Mulyana, R. (2004). Mengartikulasikan Pendidikan Nilai. Bandung: Alfabeta. .(2005). Model Pembelajaran Nilai dalam Pendidikan Agama Islam. Bandung: Alfabeta.

Ndraha, T. (1990). Membangun Masyarakat Mempersiapkan Masyarakat Tinggal Landas. Jakarta: Rineka Cipta.

Park, Joe. (1963). The Philosophy of Education. New York: The Macmillan Company.

Parsons, Talcott, Shils A.Edward. (1962). Toward a General theory of Action. America: Harper \& Row.

Phenix, P.H. (1964). Realms of Meaning. New York: McGraw-Hill Book Company.

Peraturan Pemerintah Nomor 60 tahun 1999 tentang Pendidikan Tinggi

Raven, J. (1977). Education, Values, and Society: The Objectives of Education and the Nature and Development of Compertence. London: HK Lewis \& Co. Ltd.
Reitman W. Sandford. (1977). Foundation of Education for Prospective Teachers. New York: James S. Coleman. Basic Books Inc.

Siraj, Saedah, et al. (Eds) 2005. Cognition and Learning: Issues and Strategies. Malaysia: Malindo Publications Sdn. Bhd.

Stringer, Ernest T. (1996). Action Research: A Handbook for Practitioners. London: Sage Publications.

Singarimbun, M. dan Effendi, S. (1989). Metode Penelitian Survey. Jakarta: LP3ES.

Sumaatmadja, N. (1990). Konsep dan Eksistensi Pendidikan Umum. Bandung: PPS IKIP Bandung, Bahan Perkuliahan.

Sauri, Sofyan. (2002). Pengembangan Strategi Pendidikan Berbahasa Santun di Sekolah. Disertasi Doktor pada SPs UPI Bandung: tidak diterbitkan.

Sasongko, N.R. (2001). Model Pembelajaran Aksi Sosial untuk Pengembangan Nilai-Nilai dan Keterampilan Sosial. Disertasi Doktor pada SPs UPI Bandung: tidak diterbitkan.

Smith.MB. (1969). Social Psychology and Human Values. Chicago: the Aldine Publishing Company.

Somad.A.M. (2007). Pengembangan Model Pembinaan Nilai-Nilai Keimanan dan Ketakwaan siswa di Sekolah. Disertasi Doktor pada SPs UPI Bandung: tidak diterbitkan.

Superka et al. (1975). Value Education: Approaches and Materials. Washinton D.C: National Institute of Education

Slamet, M. (2003). Membentuk Pola Perilaku Manusia Pembangunan. Bogor: IPB. Press.

Supriyatna,Tjahya. (2001). Strategi Pembangunan dan Kemiskinan. Jakarta: Rineka Cipta. 
Suseno,F.M. dan Reksosusilo. (1983). Etika Jawa dalam Tantangan. Yogyakarta:Kanisius

Sandford, W. Reitman. (1977). Foundation of Education for Prospective Teachers. New York: Basic Book Inc.

Suzetta, P. (2007). Perencanaan Pembangunan Indonesia [Online]. Tersedia: http://www.bappenas.go.id. [3 November 2007].

Sulastomo. (2010). Kepedulian Sosial [Online]. Tersedia: http://www.hupelita.com

/baca.php?id=41718. $\quad$ [8 $\quad$ Pebruari 2010].

Tafsir, Ahmad. (2006). Filsafat Pendidikan Islami: Integrasi Jasmani, Rohani dan Kalbu Memanusiakan Manusia. Bandung: PT.Remaja Rosdakarya.

Titus, H.H, (1959). Living Issues in Philosophy. New York: American Book Company.

Vicente Hao Chin Jr. (2010). Values

[Online]. Tersedia: http:

www.selftransformation.net articles values.htm. [8 Pebruari 2010].

Wallace, Gerald. (1978). Educational Assessment of Learning Problems: Testing for Teaching. Boston, London, Sydney, Toronto: Allyn and Bacon, Inc.
Wilber, Gordon O. (1962). Industrial Arts in General Education. Pennsylvania: International Textbook Company

Winston \& Jackson. (1995). Methods: Doing Social Research. Canada: Prentice Hall Canada Inc.

Widiastono D. Tonny dan Hasan, Fuad, (Eds) (2004). Pendidikan Manusia Indonesia. Jakarta: Penerbit Buku Kompas.

Wikipedia. (2010). Internalization. [Online]. Tersedia: http://en.wikipedia.org/wiki /Internalization . [8 Pebruari 2010]. . (2010). Values. [Online]. Tersedia: http://www. ilearn.senecac.on.ca/ careers/goals/ values. html. [8 Pebruari 2010]. . (2008). Participatory Action Research. [Online]. Tersedia: http://en.wikipedia.org/wiki/ Participatory_Action_Research. [16 July 2008]

Zakaria, Ramli, Teuku. (2001). "Pendekatan Pendidikan Nilai". Jurnal Depdiknas

Zais, Robert S. 1976. Curriculum: Principles and Foundations. New York. Harper \& Row Publishers 